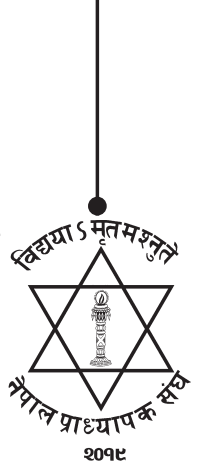

NJ: NUTA

\title{
Economic Adversity and Disgrace in Untouchable
}

\author{
Bhim Nath Regmi \\ Lecturer, Department of English \\ Tribhuvan University, Faculty of Education, Kirtipur, Kathmandu \\ Email for correspondence: regmibn@yahoo.com
}

\begin{abstract}
Mulk Raj Anand has created a unique position as a Humanist and a social writer in India writing in English. He has contributed in the development of Indian English Literature and focuses on caste issue, economic adversity and disgrace rooted in Indian society. He has public concerns and humanity for the subjugated people and his characters represent the social reality of suppressed people of India. His first novel Untouchable is an account of a day in the life of its protagonist-Bakha, an untouchable sweeper. He describes the depressed conditions of the untouchables, their immitigable hardships and physical and mental agonies almost with the meticulous skill of historical raconteur.
\end{abstract}

Key words: Anand, Indian society, economic adversity, untocuhable, outcaste, oppression, disgrace and social change.

\section{The Background}

Mulk Raj Anand occupies an important position in Indian literature writing in English. The overall study of his fictional work 'Untouchable' published in 1935; set in the so called upper caste Hindu colony outside of an unnamed town during the British rule in India; portrays the desolate life of common people. The subject matter of the novel is based on the life of the most downtrodden, despised and oppressed section of Indian society, the outcastes. Bakha an eighteen year old protagonist is the representative figure of all the downtrodden society in the pre-independence era of India. He seems proud, strong and able bodied child of the then Indian society; and believes that he is the most superior young man compared with his other fellow-outcastes. In spite of his obligation of continuing his job of sweeping the roads or cleaning the toilet, he experiences frequent disgrace and dishonor throughout the working day that brings shadows in his rest of the time.

The author reveals the socio-political, economic and cultural problems of the suppressed and oppressed people who never appeared in literature in the past. He describes the depressed conditions of the untouchables through the character Bakha, their immitigable hardships and physical and mental agonies almost with the meticulous skill of historical raconteur. It is a realistic recordation and a transcription of the pathetic plight of untouchables who are subjected to immitigable social indignities due to their low birth. Anand's description of a small family of Lakha, a sweeper, covers the problematic issue of outcaste people in the light of the abject poverty and suffering. Yavav states "the story of Bakha in the 'Untouchable' is just a struggle for emancipation from the suffering of untouchability" (p. 13). Untouchable portrays an inner conflict of an individual who is in the web of an age-old caste system 
deeply rooted in Indian society. Rajan in his Studies in Mulk Raj Anand expresses his views that the protagonist is looking for freedom and wants to bring social change. In Rajan's words:

It is the individual's quest for freedom in a social system of ruthless exploitation. Bakha as an untouchable seeks his freedom in the feudal society with its unquestionable faith in the infallibility of caste discrimination, with its hypocrisy, cruelty, deceit and inhumanity. We see him stand passive and bewildered at the immensity of horror, hoping for a change (p. 15).

\section{Caste System in India and Untouchable}

The Universal Declaration of Human Rights proclaims "all human beings are born free and equal in dignity and rights" (Article 1). Unlike this, the outcaste people like Bakha, his father Lakha -the jamadar of all the sweepers' community in the town and the cantonment, his brother Rakha and sister Sohini experience physical, psychological, cultural, and political violence repeatedly. They are subject to injustice and discrimination due to patriarchal mode of production, patriarchal relation in the state, patriarchal violence, patriarchal relation in sexuality and their relation in socio-cultural institutions.

Hindu upper caste people try to legitimatize their imposed violence upon the untouchable people. In Johan Galtung's words "cultural violence highlights the way in which the act of direct violence and the fact of structural violence are legitimized" (p. 292). The violent structure is deep rooted in the structural pattern of the society and the mind of the people. It is a part of an external dynamic which determines internal living style of the people. In this regards, Kroeber, Kluchkohn and Untereiner express their views "culture is present in persons, shaping their perceptions of events" (p. 186). In Terry Eagleton's words the dominance of ruling class is based on their own ideology of their society which tries to "legitimatize the power of ruling class in society" (p. 244).

The social affecting major problem in Hindu society came into existence with the traditional categorization of Hindu people into four groups "the Brahmins, the Kshatriyas, the Vaishyas, and the Shudras" (Parmar and Sahayak, 7). Gita a holy book of Hindu religion declares "the work of the Brahmins, Kshatriyas, Vaishyas, and Sudras is divided according to qualities born of their own inner nature" (Bhagabad Gita, Ch. 4, Verse 13). The Shudras who fall in the low caste (outcastes) perform required services to the upper caste people and carry out the work like leather workers, blacksmiths, maids, sweeping, and cleaning. They have typically not been accorded the same rights as higher castes; and are not able to use different temples and public facilities for their comforts. People in 'Untouchable' live in mud-walled cottages huddled in a colony who are the scavengers, the leather workers, the washer men, the barbers, the grass-cutters, the sweepers and other outcastes. Anand describes the condition of people in this way:

The outcastes' colony was a group of mud-walled houses that clustered together in two rows, under the shadow both of the town and the cantonment, but outside their boundaries and separate from them. There lived the scavengers, the leather- workers, the washer-men, the barbers, the water carriers, the grass-cutters and other outcastes from Hindu society (p. 11).

Anand's untouchable characters spend very pitiable time and only share their aches and agonies with the readers. Their plight is very much depressing and they have to depend on the mercy of highcaste Hindus for the fulfillment of the basic needs like water and food. Bakha who was in charge of 
cleaning public toilet, experiences physical and mental anguish on the way to town and while sweeping roads and cleaning toilets. He observes "men came one after another, towards the latrines. Most of them were Hindus" (p. 20), he feels thirsty and does not get water. He feels humiliation as the cigarette-seller and sweet-seller give him cigarette and jalebi (Indian sweet) without touching him though they do not feel hitch in taking his money. The exposition of the double standards of those high caste shopkeepers is the "product of the concrete social relations into which men enter at a particular time and place; it is the way those class-relations are experienced, legitimatized and perpetuated" (Eagleton, 245). Their hypocrisy accepts the money paid by the outcaste by splashing water on it and the shopkeeper throws the goods at them the things they pay money for. "He caught the jalebis which the confectioner threw at him like a cricket ball, placed four nickel coins on the shoe-board for confectioner's assistant who stood ready to splash some water on them" (p. 64).

The untouchable people had to clean different houses and the landlord could offer them some bread to eat. The high caste Hindus used to throe rottis (bread) at him from the top of the house and Bakha had to remain happy in his life. Charat Singh, the Havildar, had gifted Bakha with a hockey stick and when he was playing hockey with others, a small child injured. Bakha picked him up in his arms and took him to the hall of his house to save him. He felt insult when a woman spoke bitterly "you have defiled my house, besides wounding my son." This novel is a faithful record and a transcription of the pathetic plight of untouchables who were subjected to immitigable social indignities only because of their lowly birth. His father believes every injustice is the cause of their low birth and destiny. His father is the symbol of inactive submission to the exploitation by the high castes. He internalizes every force of tradition, orthodoxy and conservation prevailing in that society. He does not charge the upper caste people for the caste-based discrimination but blames himself for the result of the sin committed in the previous birth.

Anand creates sympathy by confronting supreme arrogance of the high caste exploiters against the low caste people. The upper caste people view those people who clean dirt are treated like dirty things in the community. The so called civilized people feel "They ought to be wiped off the surface of the Earth!"(p. 56). Unlike this remark, the author shows the hopelessness of the untouchables through the question of the hero "What have I done to deserve all this" (p. 133)? The story in the "Untouchable' Yadav mentions "seems to [him] is just a struggle for emancipation from the suffering of untouchability" (p. 13); and he concludes the text "ends with some solutions, as Anand perceives the whole things only extremely and mechanically as an observer" (p. 17). Similarly, in Indra Mohan's views the novel 'Untouchable'focuses on 'class distinction between the rich and poor, between the tea planters and labourers, between the high caste Hindus and the dregs of humanity, known as untouchables hamper the growth of individuals which ultimately results on social evils" (p. 105).

\section{Poverty and Economic Adversity in Untouchable}

Indra Mohan peeps out Anand's life and states that his love for outcastes and poor people is the concern for "the socially and economically oppressed came from his peasant mother and father who was a traditional copper smith" (p. 104). In this novel, the story puts stress on Bekha's hardship and caste discrimination. The protagonist is a universal figure to illustrate the oppression, injustice and humiliation committed by powerful people against the powerless civilians of that society. $\mathrm{He}$ symbolizes the economic adversity and disgrace of ordinary people which is the fate of untouchable 
people like Bakha. The economic hardships and emotional humiliation that he frequently experiences energize his physical strength and rage in his soul.

Early in the morning his father orders him to get up early "Get up. Ohe, you Bakhya, ohe, son of pig! Are you up? Get up, you illegally begotten" (p. 12). Economic exploitation has been a common cause of scarcity and famine in the countryside of India. The landlords and moneylenders exploit the peasants and become the cause of their poverty and starvation. The exploited people have to live at the mercy of the exploiters for their basic needs and they have no economic right to earn their living. Bakha as a sweeper performs his duty for the high castes and gets nothing else in return. They beg for food, water and clothes. A woman throws bread to him from the top "Vay Bakhiya, take this. Here's your bread coming down.' And she flung it at him” (p. 83). The poverty and economic adversity are the causes of humiliation - a part of regular life of ordinary people- expose the real picture of the society. At noon when Bakha reaches home, he was feeling extreme hungry; and Anand writes "Meanwhile he began to feel hungry as if rats were running around in his bell, searching for food. He began to spit a while flocculent spittle on the dust as he hurried out of the town" (p. 84), portrays the apparent problem of poor people. The description of the outcaste colony in the beginning of the novel reveals not only poverty but also the subhuman level of their existence. The entire set up of Bakha's life with his family members reveals the poverty of the downtrodden. Anand opines:

There lived the scavengers, the leather-workers, the washer men, the barbers, the water carriers, the grass cutters and other out castes from Hindu society. A brook ran near the lane, once with crystal-clear water now soiled by the dirt and fifth of the public latrines situated about it, the odour of the hides and skins of dead carcasses left to dry on its banks, the dung of donkeys, sheep, horses, cows and buffaloes heaped up to be made into fuel cakes. The absence of the drainage system had, through the rains of various seasons, made of the quarter a marsh which gave out the most offensive smell. And altogether the ramparts of human/animal refuse that lay on the outskirts of this little colony, and the ugliness, the squalor and the misery which lay within it, made it an 'uncongenial' place to live in (p. 14).

Bakha's day starts with rebuke of his father Lakha that shadows his whole day and feels humiliation in different places. Bakha is in charge of the three rows of public latrines which line the extreme end of the settlement; and he has to clean them in time. Anand writes:

Men came one after another, towards the latrines. Most of them were Hindus, naked, except for the loin-cloth, brass jugs in hand and with the sacred thread twisted round their left ears occasionally came a Muhammadan, who wore a long, white cotton tunic and baggy trousers, holding a big copper kettle in his hand (p. 20). Denial of education to the outcastes is a part of socio-political exploitation. Bakha aspires to join the school for getting education when he was a child. He remembers the views of his father that made him helpless and pathetic "the schools were meant for the babus, not for bhangis. He hadn't understood the reason for that then"(p. 54). In fact, he was incapable of getting education due to the abject poverty and his low birth rate which was not entertained by Indian society. Bakha had four annas (coins) and wanted to buy some sweets to eat and asked the shopkeeper to give him jalebis. The incident of his willingness to buy some 
sweets reveals his poverty. He considers 'Dare I buy some sweets' (p. 62)? Finally, he decides to buy jalebis and the sweet-seller opines "sweepers should not buy sweets, if at all they buy, it should only be coarse stuff like jalebis" (p. 63). The Indian society exploits the outcaste people in economic level too. The sweetmeat-seller manipulates the scales to cheat the outcastes knowing that they will not protest. "The shopkeepers always deceived the sweepers and poor people, charging them much bigger prices, as if to compensate themselves for the pollution they allowed by dealing with the outcastes" (p. 63).

Hindu woman throws a chapattito him from top of her house and he feels disgrace to pick it up. The entire family of Bakha depends on the grace of high caste Hindus for their meals. Even then he fails to get adequate food for their lunch, Rakha, his brother goes for begging food; and realizes their condition of poverty. Bakha watches the beggars at the railway station and observes the miserable condition of poor people "a sadistic delight staring at the beggars moaning for alms but not receiving any" (p. 183). Their moaning, wailings and crying sound exhibit the poverty at the railway station. Anand ststes that:

The pavements were crowded with beggars. A woman wailed for food outside one of many cook shops which lined one side of the road. She had a little child in her arms, another child in her bag on her back, a third holding on to her skirt. Some boys were running behind the stream of carriages begging for coppers (p. 183).

\section{Disgrace and Exploitation in Untouchable}

Anand's characters are born and bred in abject poverty. The hopelessness condition and miserable circumstances of the characters drive them to pave the way to confront with the reality of romantic illusions of human lives. They live to manage their own food under the age-long colonial yoke of dejection and debauchery born on exploitation of colonial rulers and Indian elites who always deprive them of their dignity of labour and human values. His sister Sohini experiences the onslaught of the upper class people and humiliation in the area when she approaches in the well to fetch water for her brother Bekha. She knows her brother is tired and thirsty. She waits for a long time to get a chance of collecting water as untouchables don't have their well. Anand marks:

The outcastes were not allowed to mount the platform surrounding the well, because if they were ever to draw water from it, the Hindus of the three upper castes would consider the water polluted. Nor were they allowed access to the nearby brook as their use of it would contaminate the stream. They had no well of their own because it cost a lot of money to dig a well in such a hilly town as Bulandshahr. Perforce they had to collect at the foot of the caste Hindu's well and depend on the bounty of some of their superiors to pour water into their pitchers (p. 26).

This type of humiliation is very common for untouchable and they have accepted as an agelong old tradition. Even she waited a lot to have her turn and other outcastes also waited but they cannot touch the well and have to wait for upper class Hindu to give her water in her pot. Anand comments:

She had come as fast as she could to the well, full of fear and anxiety that she would have to wait her turn since she could see from a distance that there was already a crowd. She didn't feel disappointed so much as depressed to realize that she would be the eleventh 
to receive water. She had sensed the feeling in her brother's soul. He was tired. He was thirsty. She had felt like a mother as she issued from her home to fetch water, a mother going out to fetch food/drink for her loved ones at home. Now as she set in a row with her fellow sufferers, her heart sank (p. 27).

This realistic description illustrates Anand's art of narration that makes the readers feel compassionate for the ill-treatment with untouchables. It was a general treatment with outcaste people in the early decades of twentieth century in India. Gulaboo, the washerwoman being jealous of Sohini abuses her in the novel:

Think of it! Think of it! Bitch! Prostitute! Wanton! And your mother hardly dead. Think of laughing on my face, laughing at me who an old enough to be your mother. Bitch!' the washerwoman exploded. Ari, bitch! Do you take me for a buffoon? What are you laughing at, slut? Aren't you ashamed of showing your teeth to me in the presence of men, prostitute? (pp. 28-29)

Pundit Kali Nath, one of the Hindus, gave water for her and called her to his house to clean the courtyard and tried to assault her. Sohini began to cry loudly to protect herself, and Pundit cried out "polluted", "polluted" (p. 89). Anand has depicted it beautifully as a hypocrisy and lust of so called priest Pundit Kalinath who believes the untouchable people pollute water and his body by their physical touch but he does not have any problem to feel a strong sexual desire with Sohini, an untouchable. Bakha is in extreme pain as he could not do anything to Pundit and remains a mute witness. He desperately went home and told his father, and says it is a curse to have beautiful sister as people look toward the lustfulness and he could not do anything. He utters:

My poor sister! How can she show her face to the world after this? But why didn't she let me go and kill that man? Why was she born a girl in our house, to bring disgrace upon us? So beautiful! So beautiful and so accursed! I wish she had been the ugliest woman in the world. Then no one would have teased her! But he couldn't bear the thought of her being ugly! His pride in her beauty seemed to be hurt. And he just wished: 'Oh, God, why was born, why she was born'. Then, however, he saw her bending and wiping her eyes with her apron. With a sudden burst of tenderness and humility he gripped her arm close and dragged her along writhing with the conflicts in his soul (p.74).

Sohini becomes the victim of sexual exploitation due to her social group and poverty. She is very beautiful and does not have enough clothes to cover her body and failed to protect her beauty from the male-Pundit Kalinath. Saros Cowasjee observes "her figure could have vied with the sculptured images of Konark and Khajurao, but she has been condemned by birth to walk the path of the outcastes and to suffer their mortification" (p. 90). Anand has an outstanding kindness for the protagonist who symbolizes the predicament of a miserable victim pitted against the forces of orthodoxy and conservatism. At one point a house wife throws pancakes to Bekha and uses abusive language to dominate him. The upper caste people have a strong faith that the untouchable people fall under the category of subhuman species between humans and dogs. She speaks "why did you sit down on my doorstep, if you had to sit down at all? You have defiled my religion! You should have sat there in the gully. Now I will have to sprinkle holy water all over the house. Spoiler of my salt! Oh, how terrible! You sweepers have lifted your heads to the shy, nowadays" (p. 81). 
Anand feels such social discrimination is the cause of Hindu religion. He condemns the temples as being the instruments of disgrace and exploitation. His sarcastic remark on Hindu gods and rituals comes out as the high castes use their gods for their own advantage. The Hindu gods and rituals create fear in the minds of the outcastes. Bakha feels 'The temple seemed to advance towards him like a monster" (p. 82). Bakha feels helplessness and when Pundit Kali Nath molests his sister. "He felt he could kill them all. He looked ruthless, deadly, pale and livid with anger and rage" (p. 86). Immediately his sense of fear comes back and feels weak. "He could not overstep the barriers which conventions of his superiors had built up to protect their weakness against him" (p. 89). His father Lakha is a passive submissive of every discrimination and embarrassment. He is afraid of his son Bakha when he talks about retaliation. Lakha says "we cannot do that. They are our superiors. One word of theirs is sufficient against all that we might say before the police. They are our masters. We must respect them and do as they tell us. Some of them are kind" (p. 109). The final outburst came out from Bakha touches the heart of conscious readers. It looks like that Anand was waiting to write the outburst of Bakha; even 'Bakha burst out with an explosion more sudden than the manner in which he was normally wont to utter a speech. He argues:

They insulted me this morning; they abused me because as I was walking along a man happened to touch me. He gave me a blow. And a crowd gathered round me, abusing and they think we are mere dirt because we clean their dirt. That pundit in the temple tried to molest Sohini and then came shouting: "Polluted, polluted." The woman of the big house in the silversmith's gully threw the bread at me from the forth storey. I won't go down to the town again. I have done with this job (p. 89).

\section{Realization of the Problems}

The upper class people show their double standard in the case of untouchability. Anand illustrates the ideas that Sohini is a passive sufferer of humiliation like her father Lakha. The reflection of ill activities of the high caste Hindu people towards Bakha and Sohini reveal injustice, socio-cultural discrimination and disgrace. Finally Bakha -a protagonist, realizes the twin problems of caste division and poverty that causes humiliation in Indian society. Bakha along with his sister becomes the victim of the people and gets no help from his father to get rid of all social miseries. In E. M. Forster words "Bakha is a real individual, lovable, thwarted, sometimes grand, sometimes weak, and thoroughly Indian" (p. 9). Even at present Untouchable is a significant text in Indian society as the naked realities of social evils and dismal condition of untouchable people still exist in the society.

\section{References}

Anand, M. R. (1981). Untouchable. New Delhi: Arnold Publishers.

C. Bhaktivedanta Swami Prabhupada (1986). Bhagavad Gita: As it is. India: The Bhaktivedanta Book Trust.

Cowasjee, S. (1977). So Many Freedoms: A Study of Major Fictions of Mulk Raj Anand. New York: Oxford University Press.

Eagleton, T. (2004). "Marxist Criticism.” In D. Walder(Ed.), Literature in the Modern World: Classical Essays and Documents (pp.243-251).New York: Oxford University Press.

Forster, E. M. (1981). "Preface.” Untouchable. New Delhi: Arnold Publishers. 
Galtung, J. (1977). Methodology and Ideology. Essays in Methodology, Volume. I. Copenhagen: Ejlers.

Indra Mohan, T. M. J. (2005). "Mulk Raj Anand's Untouchable: A Social Document." The Novels of Mulk Raj Anand. Delhi: Atlantic Publishers.

Kroeber, A. L., Kluchkohn, C. \& Untereiner, W. (1952). Culture: a Critical Review of Concepts and Definitions, New York: Vintage Books.

Parmar, V. G. \& Sahayak, A. (2012). “Exploitation of Teenagers as Reflected in Mulk Raj Anand's Untouchable and Coolie"Research Expo International Multidisciplinary Research Journal, 2 (3), 4-9.

Rajan, P. K. (1986). Studies in Mulk Raj Anand. India: Abhinav Publication.

UN (1948). Universal Declaration of Human Rights 1948. Print.

Yadav, S. K. (2005). A Comparative Study of Mulk Raj Anand's Untouchable and Sharan Kumar Lambale's Akkarmashi. In T. M. J. Indra Mohan (Ed.), The Novels of Mulk Raj Anand. Delhi: Atlantic Publishers, 2005. 9-18. Print. 